\title{
BIO-FERTILIZING EFFICIENCY OF PHOSPHATE SOLUBILIZING BACTERIA IN NATURAL ENVIRONMENT: A TRIAL FIELD STUDY ON STRESS TOLERANT POTATO (SOLANUM TUBEROSUM L.)
}

\author{
JAHANGIR, G. Z..$^{1,3 *}$ - ARSHAD, Q.-U.-A. ${ }^{2}-$ SHAH, A. ${ }^{1}-$ YOUNAS, A. ${ }^{3}-$ NAZ, S. ${ }^{3}-$ ALI, Q. ${ }^{4 *}$ \\ ${ }^{I}$ Centre for Applied Molecular Biology (CAMB), University of Punjab, Lahore, Pakistan \\ ${ }^{2}$ Departments of Zoology, University of Punjab, Lahore, Pakistan \\ ${ }^{3}$ Department of Biotechnology, LCWU, Lahore, Pakistan \\ ${ }^{4}$ Institute of Molecular Biology and Biotechnology, University of Lahore, Lahore, Pakistan \\ *Corresponding authors \\ e-mail:zahra_jahangir@yahoo.com,saim1692@gmail.com
}

(Received 14 $4^{\text {th }}$ Mar 2019; accepted 24 $4^{\text {th }}$ May 2019)

\begin{abstract}
The present study aimed at the characterization of various strains of phosphate solubilizing bacteria (PSB) purified on Pikovskaya (PVK) agar medium, containing insoluble tricalcium phosphate (TCP). Maximum phosphate solubilization index (PSI) was calculated from 1.1 to $4.57 \mathrm{~cm}$ from clear halo zones around the microbial growth on the PVK. 26 highly efficient purified PSB isolates were also found effective for potassium solubilization on Aleksandrov medium. Maximum potassium solubilization index (KSI) was calculated as $1.1-4.66 \mathrm{~cm}$. The phosphate and potassium solubilization is linked to the production of low molecular weight acids by bacterial cells. Therefore change/decline in the $\mathrm{pH}$ of liquid cultures was also observed and maximum decrease was recorded as 3.25 in 9AS strain. Most efficient strains were characterized by ribotyping and based on sequence studies were identified under genera Klebsiella, Enterobacter, Bacillus, Marine bacterium, Staphylococcus, and Serratia. Their sequences obtained MF465778, MF465779, MF465782, MF465781, MF465777, and MF465783, respectively (GenBank). Bio-fertilizing efficiency and possible plant growth promoting effect of selected PSB was evaluated by applying in potato (Solanum tuberosum L.) rhizosphere in trial field. An increase of, twofold yield in plant height, number of lateral shoots, number of roots and root length was observed by Bacillus licheniformis, Serratia marcescens, and Staphylococcus warneri, as compared to un-inoculated controls. These results indicate that the isolated strains bear great potential to be used as source of bio fertilizer in crop fields.
\end{abstract}

Keywords: $P S B, K S B$, biofertilizer, potato trial field, molecular characterization

\section{Introduction}

Phosphorus (P) being an essential macro nutrient is indispensable for plant's growth (Leticia et al., 2015). Unlike nitrogen, there is no atmospheric reservoir available to augment its quantity in soil. Phosphorus in soil is present both in the form of organic and inorganic phosphates. Inorganic phosphates form large mineral complexes with other metals in the soil. While on the other hand, organic phosphates, which constitute $20-80 \%$ of total phosphorus contents in soil, are present as immobilized and insoluble phosphates (Diep et al., 2013). Phosphorus that is absorbable by plant roots exists in scarce amount in soil. The amount of P deviates between $200-2000 \mathrm{~kg} P /$ ha at upper $15 \mathrm{~cm}$ soil layer, having an average amount of about $1000 \mathrm{~kg}$ present in soil but its available quantity is a lower fraction of phosphorus available (Ali et al., 2013; Jahangir et al., 2016), that is roughly $10 \mu \mathrm{M}$ in different soils (Nobandegani et al., 2015). A recent 
investigation suggested that although $95-99 \%$ of all phosphoric amount is in insoluble forms, however only $0.1 \%$ of it, is in plant's accessible form (Ali et al., 2014, 2016; Awais et al., 2017; Surapat et al., 2013). Thus, plants need assisting agents to convert immobilized and insoluble phosphorus into a form that can be absorbed readily through roots.

Nature has richly supplied the agricultural soils with phosphate solublizing bacteria (PSB). These bacteria are one of the many other types of Plant growth-promoting bacteria (PGPB) which aid plant growth and development through various mechanisms (Glick, 2001). PSB are found to convert insoluble phosphates, in a form accessible to plants, such as orthophosphate (Leticia et al., 2015), through solubilization and mineralization. Animal dung has long been used to increase the P contents of soil ignoring the microbial communities and their roles (Sharma et al., 2011). Thus, PSB application to increase the rhizospheric phosphorus levels by solubilization of reprecipitated P forms is favored (Shekhar et al., 2000; Sadiq et al., 2013). In addition, application of KSB biofertilizers is not only associated with the improvement of soil fertility but also increases the crop yield. It also assists in shielding the plants from hazardous diseases plus lowers the solicitation of various synthetic fertilizers being expensive. Application of the PSB also minimizes the cost of the synthetic fertilizers in a much eco-friendly manner (Sindhu et al., 2010; Sheng et al., 2003; Zameer et al., 2015).

The purpose of the present study aimed for the isolation and molecular characterization of efficient PSB strains through ribotyping. The potential of potent strains for the development of plant growth is also evaluated in natural open environment on potato trial field that showed significant results. The Present investigation reports Bacillus licheniformis, Serratia marcescens, and Staphylococcus warneri are potential candidates to develop economical source of phosphate fertilizers that enhance plant growth and also help to reuse the fixed soil phosphate.

\section{Materials and methods}

\section{Soil sampling}

To isolate growth promoting rhizobacteria, soil samples were collected from crop rhizosphere of different agricultural areas of Punjab in the months of August-October. Soil adhering to plant roots was taken from about $20-24 \mathrm{~cm}$ depth. The soil samples were collected in disinfected polythene bags and were carried to the research laboratory of the Centre for Applied Molecular Biology (CAMB) Lahore. Soil samples were kept at $4 \pm 1^{\circ} \mathrm{C}$ until further use.

\section{Purification of PSB strains from rhizospheric soils}

For the isolation of PSB strains, the tiny roots with adhering soil were removed weighing about $1 \mathrm{~g}$ (per sample) in a formerly sterilized mortar. $6 \mathrm{ml}$ of normal saline was poured in individual sample and crushed moderately with sterilized pestles. The soil suspension from each sample was serially diluted by $10 \mathrm{x}$ factor in saline water to get better isolation. Serially diluted soil samples, $10 \mu 1$ of diluent was spread on synthetic Pikovaskaya (PVK) agar medium (Merck, B.N. \#JE2JF62127), and was sterilized at $121^{\circ} \mathrm{C}$ and $105 \mathrm{kPa}$ for $15 \mathrm{~min}$, incubated at $28^{\circ} \mathrm{C}$ (binder, MB64585923, $240 \mathrm{~V}$ and $50 / 60 \mathrm{~Hz}$ ). After initial incubation of $48 \mathrm{~h}$, single colonies that produced halo 
zones were repeatedly streaked on PVK agar plates until purified cultures were obtained. Purified cultures were preserved in $20 \%$ glycerol at $-80{ }^{\circ} \mathrm{C}$.

\section{Phosphate solubilization}

Single colonies of purified PSB isolates were inoculated into $10 \mathrm{ml} \mathrm{LB}$ broth medium in $50 \mathrm{ml}$ separate culture tubes. LB medium contained Tryptone (DIFCO\#0349000), $10 \mathrm{~g} / \mathrm{L} ; \mathrm{NaCl}, 10 \mathrm{~g} / \mathrm{L} ;$ Agar (bioworld\#40100044-1), $15 \mathrm{~g} / \mathrm{L}$ and Yeast Extract (Fluka\#0001415579), $5 \mathrm{~g} / \mathrm{L}$, and was sterilized at $121^{\circ} \mathrm{C}$ and $105 \mathrm{kPa}$ for $15 \mathrm{~min}$. For obtaining the optimal growth, these cultures were incubated overnight at $28{ }^{\circ} \mathrm{C}$ in constant shaking incubator (New Brunswick scientific classic C24KS). For pin point inoculation $10 \mu \mathrm{l}$ of each of this fresh grown culture was dripped in the middle of respective labelled PVK agar plates and incubated for 7 days at $28^{\circ} \mathrm{C}$. The phosphate solubilization index (SI) of phosphate solubilizing bacteria was calculated on seventh day using the following formula:

$$
\text { PSI }=\frac{(\text { Colony diameter }+ \text { halo zone diameter })}{\text { Colony diameter }}
$$

Based on higher phosphate solubilization index, 11 superior isolates were selected for further characterization.

\section{Potassium solubilization}

The efficient PSB isolates with higher PSI were also analyzed for assessing their proficiency to dissolve bounded potassium. The solubilization of potassium was assessed by the same protocol and formula as the phosphate solubilization; however, Aleksandrove media was used to calculate the potassium solubilization index (KSI). This modified Aleksandrove medium/L contained $\mathrm{CaCO}_{3}: 0.10 \mathrm{~g}$, Glucose: $5.0 \mathrm{~g}, \mathrm{MgSO}_{4} 7 \mathrm{H}_{2} \mathrm{O}: 0.50 \mathrm{~g}$, $\mathrm{FeCl}_{3}$ : $0.006 \mathrm{~g}, \mathrm{Ca}_{3}\left(\mathrm{PO}_{4}\right)_{2}: 2.0 \mathrm{~g}$, Insoluble Mica powder (insoluble potassium source): $3.0 \mathrm{~g}$ and Agar: $20.0 \mathrm{~g}$, and was sterilized at $121^{\circ} \mathrm{C}$ and $105 \mathrm{kPa}$ for $15 \mathrm{~min}$. Disinfected water was used for medium preparation with $\mathrm{pH}$ adjustment of 5.5-5.7.

\section{pH change}

Single purified colony of all PSB isolates was inoculated in $10 \mathrm{ml}$ of PVK broth to assess the $\mathrm{pH}$ change of the medium. Cultures were incubated in the shaker incubator (New Brunswick scientific classic C24KS) at $120 \mathrm{rpm}$ and $28{ }^{\circ} \mathrm{C}$ for ten days along with un-inoculated control. The $\mathrm{pH}$ of isolate was measured by a $\mathrm{pH}$ meter (Bante, 210) on 1st, 3 rd, 7 th and $10^{\text {th }}$ day of incubation.

\section{Molecular characterization of PSB strains based on 16SrRNA conserved regions}

11 superior isolates (based on their solubilizing efficiency) were selected for molecular characterization. Bacterial DNA was extracted using a buffer $(50 \mathrm{ml})$ that contained $5 \mathrm{M}$ $\mathrm{NaCL}, 5 \mathrm{ml}$; $0.5 \mathrm{M}$ EDTA, $5 \mathrm{ml}$; Tris of $\mathrm{pH} 7.9,5 \mathrm{ml}$ and autoclaved distilled water, $35 \mathrm{ml}$. Other reagents of protocol include Phenol Chloroform Isoamylalcohol (25:24:1), $10 \%$ SDS, $70 \%$ Ethanol, Isopropanol and glass beads. $10 \mathrm{ml}$ of sterilized LB broth medium was inoculated with single colony of each of the 11 PSB isolates in aseptic conditions. Cultures were incubated overnight, in shaker incubator at $28{ }^{\circ} \mathrm{C}$ to obtain 
optimal growth. After incubation, the culture was dispensed into $1.5 \mathrm{ml}$ microcentrifuge tubes and cells were harvested from each culture by tight centrifugation at $3000 \mathrm{rpm}$ for about $10 \mathrm{~min}$. Cell pellets were resuspended in DNA extraction buffer $(500 \mu 1 / 1.5 \mathrm{ml}$ of each culture) and dispensed in correctly labeled $1.5 \mathrm{ml}$ micro centrifuge tubes. Each tube was given a heat shock up to $65^{\circ} \mathrm{C}$ for the duration of $30 \mathrm{~min}$. After cooling for $5 \mathrm{~min}$, $100 \mu \mathrm{l}$ of $10 \%$ SDS was added and were again given the $65^{\circ} \mathrm{C}$ heat shock for $10 \mathrm{~min}$. After cooling for about $5 \mathrm{~min}$, added the $200 \mu \mathrm{l}$ of glass beads along with $200 \mu \mathrm{l}$ of PCI. Each sample was subjected to vortex after $1 \mathrm{~min}$ incubation in freezer. After repeating this step three times, samples were centrifuged on $14000 \mathrm{rpm}$ for $10 \mathrm{~min}$ and their supernatants were collected in a new $1.5 \mathrm{ml}$ microcentrifuge tubes and added with equal volume of Isopropanol. Further, tubes were centrifuged at $14000 \mathrm{rpm}$ for $10 \mathrm{~min}$. Pellet was saved and washed with $500 \mu \mathrm{l}$ of $70 \%$ Ethanol on $14000 \mathrm{rpm}$ for $7 \mathrm{~min}$. After washing, DNA pellets are dried for about $10 \mathrm{~min}$ at room temperature and then resuspended them in the $50 \mu \mathrm{l}$ nuclese-free water and stored at $-20^{\circ} \mathrm{C} 4 \mu 1$ of each sample was run on $11 \%$ agarose gel using $1 \mu \mathrm{l}$ of $6 \mathrm{X}$ loading dye in 1XTAE buffer. Each sample of DNA was also quantified through nanodrop analysis. PCR was optimized to amplify 16S rRNA gene sequence using a universal primer (Laticia et al., 2015):

\section{FORWARD PRIMER: $\quad$ 5'- GAGAGTTTGATCCTGGCTCAG-3'}

\section{REVERSE PRIMER: $\quad$ 5'- CTACGGCTACCTTGTTACGA-3'}

Annealing temperature and other amplification conditions were optimized in Gradient thermal cycler (BIO-RAD $\mathrm{T} 100^{\mathrm{TM}}$ ). PCR reaction mixture contained $100 \mathrm{ng} / \mu \mathrm{l}$ of template ( $4 \mu \mathrm{l}$ of 14AS DNA), 1mM dNTPs, 1X PCR Buffer, 1.0 picomol, each of Forward and Reverse Primers, $2.5 \mathrm{mM} \mathrm{MgCl}_{2}$, and $0.5 \mathrm{U}$ of Taq Polymerase (Thermo Scientific). Final volume made up to $20 \mu \mathrm{l}$ with nuclease free $\mathrm{H}_{2} \mathrm{O}$. The cycling conditions included initial denaturation at $95^{\circ} \mathrm{C}$ for 3 min followed by 35 incubation repeats of $45 \mathrm{~s}$ denaturation at $95{ }^{\circ} \mathrm{C}, 45 \mathrm{~s}$ annealing at gradient of $54{ }^{\circ} \mathrm{C}, 55^{\circ} \mathrm{C}, 56{ }^{\circ} \mathrm{C}$, $57^{\circ} \mathrm{C}, 58^{\circ} \mathrm{C}, 59^{\circ} \mathrm{C}$ and $1 \mathrm{~min}$ extension at $72^{\circ} \mathrm{C}$ with the final extension of $7 \mathrm{~min}$ at $72{ }^{\circ} \mathrm{C}$ and infinity hold at $4{ }^{\circ} \mathrm{C}$. After optimization, same cycling conditions were practiced for amplification of 16SrRNA gene sequences from all six best performing strains. PCR products were run on $1 \%$ agarose gel along with 100 bp DNA ladder (Thermo Scientific\#SM0323) in 1XTAE buffer. Amplified bands were purified using Invitrogen, Purelink ${ }^{\mathrm{R}}$ Quick Gel Extraction Kit \# K2100-12).

Purified 16S rRNA PCR products were sequenced by DNA core facility of the CAMB. Sequence data was analyzed and used for molecular identification of the studied PSB strains. The obtained sequences were BLAST, aligned and compared with the standard sequences in NCBI of all bacterial lineage based on information related to 16SrRNA gene sequences available on the online portal of National Center for Biotechnology Information GenBank (http://www.ncbi.nlm.nih.gov/). Further analyses were made on MEGA 6, and the phylogenetic trees for PSB strains were constructed through neighborjoining method.

\section{Trial field experiments of PSB isolates on potato crop}

Bacillus licheniformis, Staphylococcus warneri, and Serratia marcescens (14 AS, Rl, and $5 \mathrm{Bl}$ respectively) were applied in the rhizospheric region of 25 abiotic stress tolerant potato plants (Sante) in a trial field to test their biofertilizing efficiency in the 
natural environment. Field trial study was conducted in the area of CAMB specified for potato trial field within trial field premises of CAMB during October-January 2017.

The trial field land was prepared by using different irrigational practices and was supplied with essential amount of fungicide and inorganic fertilizers for adequate crop growth. The soil of trial field was sandy loam and an adequate quantity of organic matter was mixed during softening of soil. The $\mathrm{pH}$ of trial field soil was 6.5 on the day of plantation. No extra fertilizer was applied during whole experiment. All other requirements of the field including watering and soil softening were provided as per need of the crop. The Lab grown complete plants of tissue cultured transgenic Sante variety (possessing Dehydrin-10 gene of Eucalyptus) was shifted to the trial field. Following the plantation pattern of Skogsmyr (1994), the plants were planted (shifted) to trial field soil at distance of 0.25 to $0.5 \mathrm{~m}$. Overnight grown bacterial culture $(10 \mathrm{ml}$ per plant) was applied to the rhizosphere soil of plantlets in three repeated treatments on 7 th, 21 st, and 50th day of plantation. The potato field was harvested on $90^{\text {th }}$ day after shifting the plants into trial field from laboratory. The number of survived plants per experimental units, number of lateral shoots per plant, total number of roots and tubers (of all sizes) per plant, maximum root and shoot length per plant were measured and recorded for all three treatments and, negative control lanes.

\section{Statistical analysis}

The obtained experimental data were analyzed statistically by using Statistix software version 8.1 and the results were expressed as the mean. Means and standard errors (SE) separation was accomplished by LSD. Statistical analysis of the results was performed by using general linear model (GLM) and one-way analysis of variance (oneway ANOVA) up to 5 levels to access whether the different PSB isolates had a significant effect on plant growth parameters. Significance of the effect of treatment was determined by the magnitude of the value $(P<0.05)$.

\section{Results and discussion}

\section{Purification and phosphate solubilization potential of PSB}

Phosphate Solubilizing Microbial colonies that were purified on the Pikovskaya (PVK) agar medium containing insoluble tri-calcium phosphate (TCP), (Fig. 1). Insoluble $\mathrm{P}$ was consumed by all isolates to different extents but eleven samples namely 2CQ1V, 2CQ11, 2CQ11l, 2CQV, 9AS, 2CQV1, 14AS, GRl, GRll, 5BI and 17AS exhibited greater halo zones on PVK agar plates, hence showed higher PSI (Fig. 2). 14AS showed highest halo zone measured as $3.2 \mathrm{~cm}$ with the PSI of $4.57 \mathrm{~cm}$. Whereas the lowest halo zone measurement was recorded as $1.1 \mathrm{~cm}$ in 3SQII. Similar methodology related to isolation and screening of PSB has been reported by scientists (Sadiq et al., 2013; Zameer et al., 2016; Jahangir et al., 2016). Values of Phosphate solubilizing index (PSI) based on their colony diameter and clear zones, differed for different PSB isolate. Similar results were stated by Yasmin et al. (2011).

\section{K solubilization potential of the PSB isolates}

PSB isolates with higher PSI were also evaluated for potassium solubilization efficiency. These potassium solubilizing microbes increase plants growth as a result of solubilization of insolvable K minerals like mica and feldspar (Sheng et al., 2003). All 
of the tested PSB isolates consumed Aleksandrov medium yielding various sized colonial growth while 3SQIV isolate showed disperse pattern of growth. While, 14 PSB isolates namely 2CQII, 2CQV, 2CQIII, 63dII, 2CQIV, 5GQI, 2CQVI, 2CQVIII, 9AS, GRII, 14AS, GR1,17AS and 5B1 were found to be capable of solubilizing K from insoluble K-bearing minerals source and the zone of solubilization was measured from 4.66 to $1.1 \mathrm{~cm}$ (Fig. 3). The research by Zhang and Kong (2014), also demonstrated the ability of the potassium solubilization from insoluble potassium. Maximum measurement of the colony and halo zone diameter was recorded by 2CQVI $(1.7 \mathrm{~cm})$ and 2CQVIP $(1.1 \mathrm{~cm})$ respectively (Fig. 3). The overall highest recorded value of KSI was shown by $2 \mathrm{CQVl}$ as $4.66 \mathrm{~cm}$ (Fig. 3). The distinct patterns of $\mathrm{P}$ and $\mathrm{K}$ Solubilization on respective growth media for comparative efficiency of PSB isolates are presented in (Figs. 4 and 5).

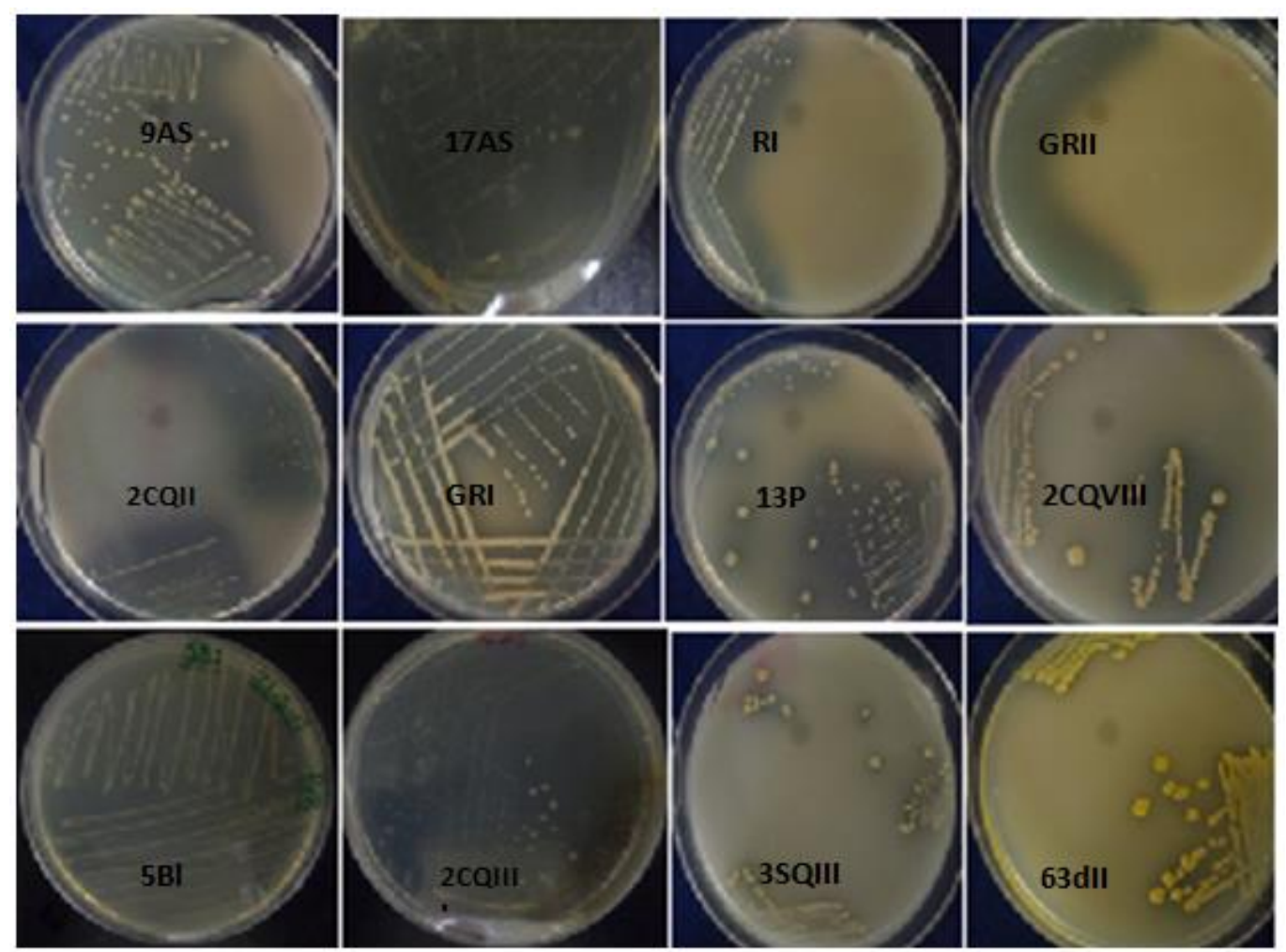

Figure 1. Purified PSB isolates on PVK medium

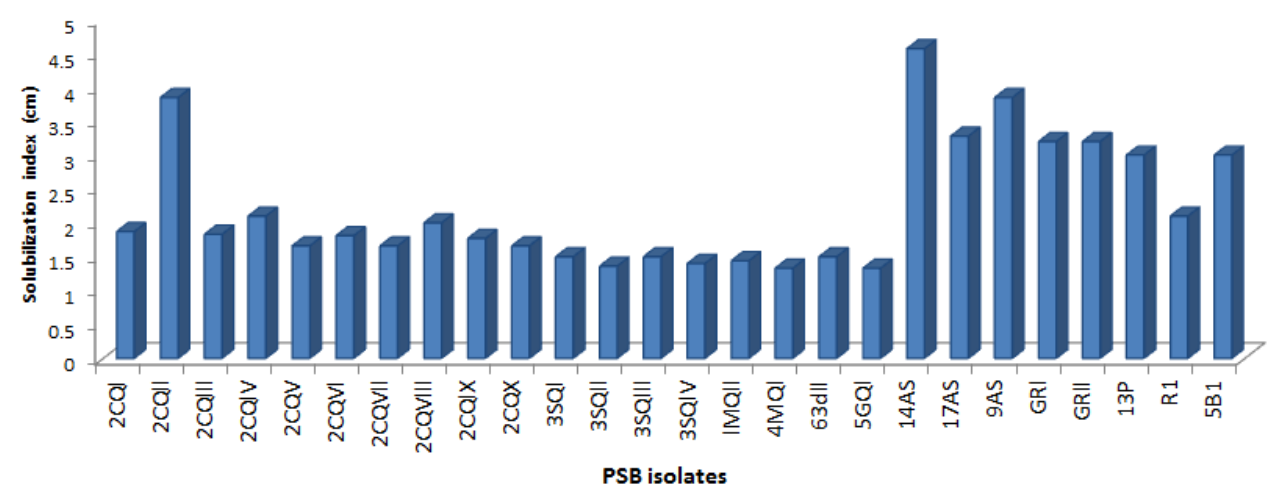

Figure 2. PSI of purified PSB isolates on PVK 


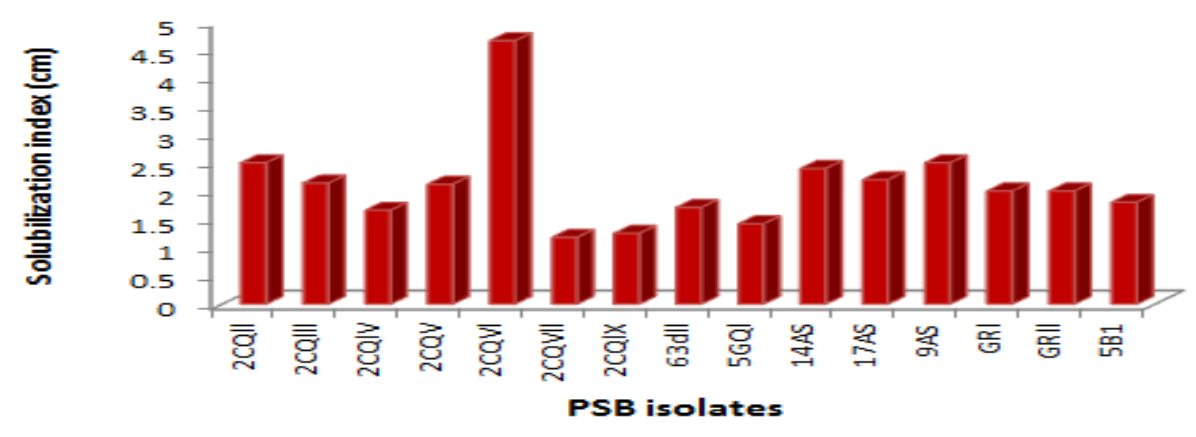

Figure 3. KSI of selected PSB isolates on Aleksandrov medium
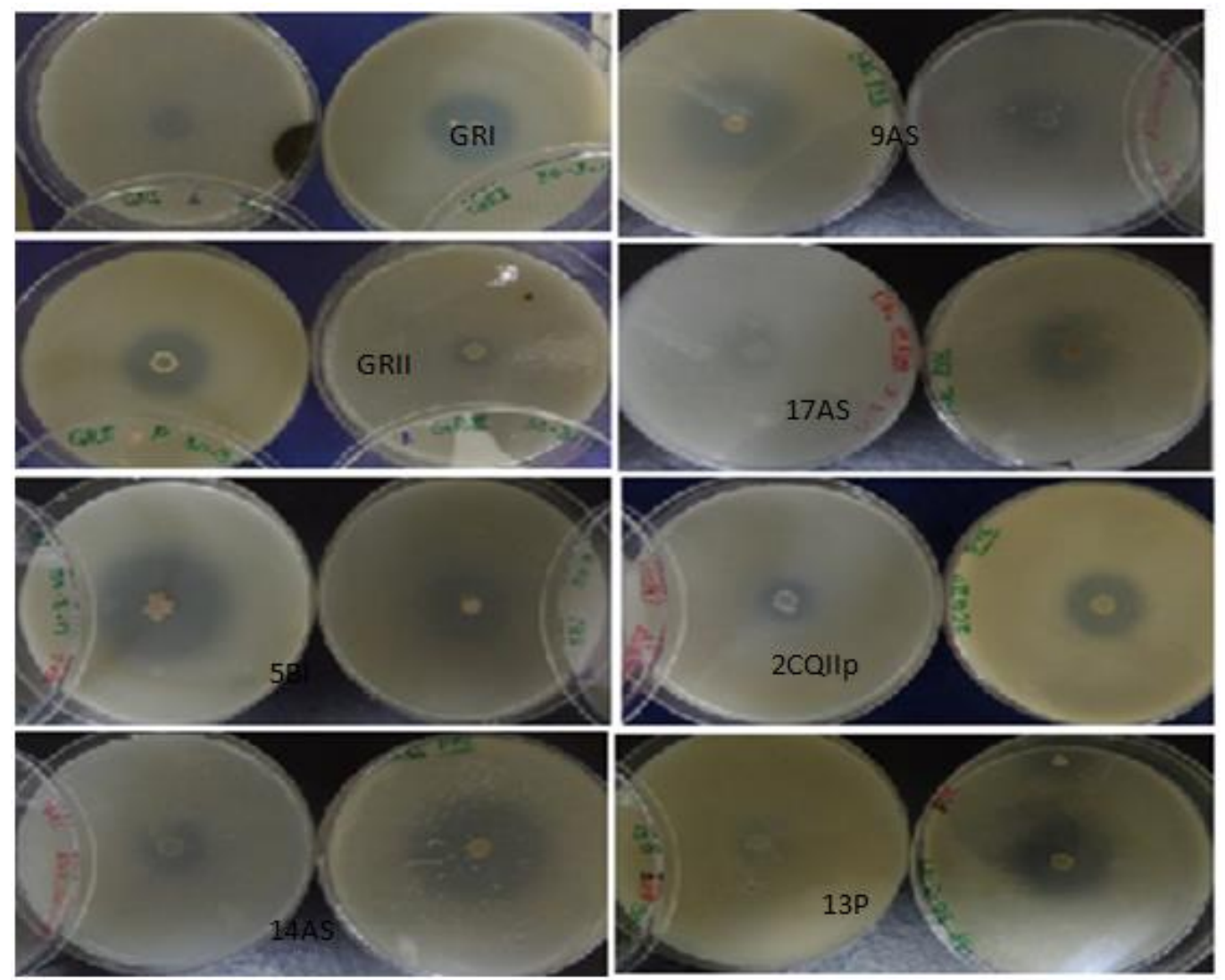

Figure 4. Comparison of some PSB isolate's Solubilization index (SI) on Pikovskaya's and Aleksandrov media

\section{pH change}

A successive decrease in all of the isolates was observed on $1^{\text {st }}, 3^{\text {rd }}, 7^{\text {th }}$ and $10^{\text {th }}$ days. Maximum recorded acidic value was of 9AS (3.25) depicting the highest medium discoloration because of breakdown of insoluble precipitates of tricalcium phosphate (Fig. 6). However, 5 cultures 2CQ11l, 2CQlV, 2CQVl, 2CQX and 63dll, showed distinct patterns of $\mathrm{PH}$ change by giving much lower $\mathrm{pH}$ values at start then a bit increase in these values on successive day but showed overall trend towards acidic property (Fig. 6). The results of the presented study are in close accordance with the findings of 
Perez et al. (2007), who reported 3.2-4.0 units decrease in the $\mathrm{pH}$ of medium due to phosphate solubilization.

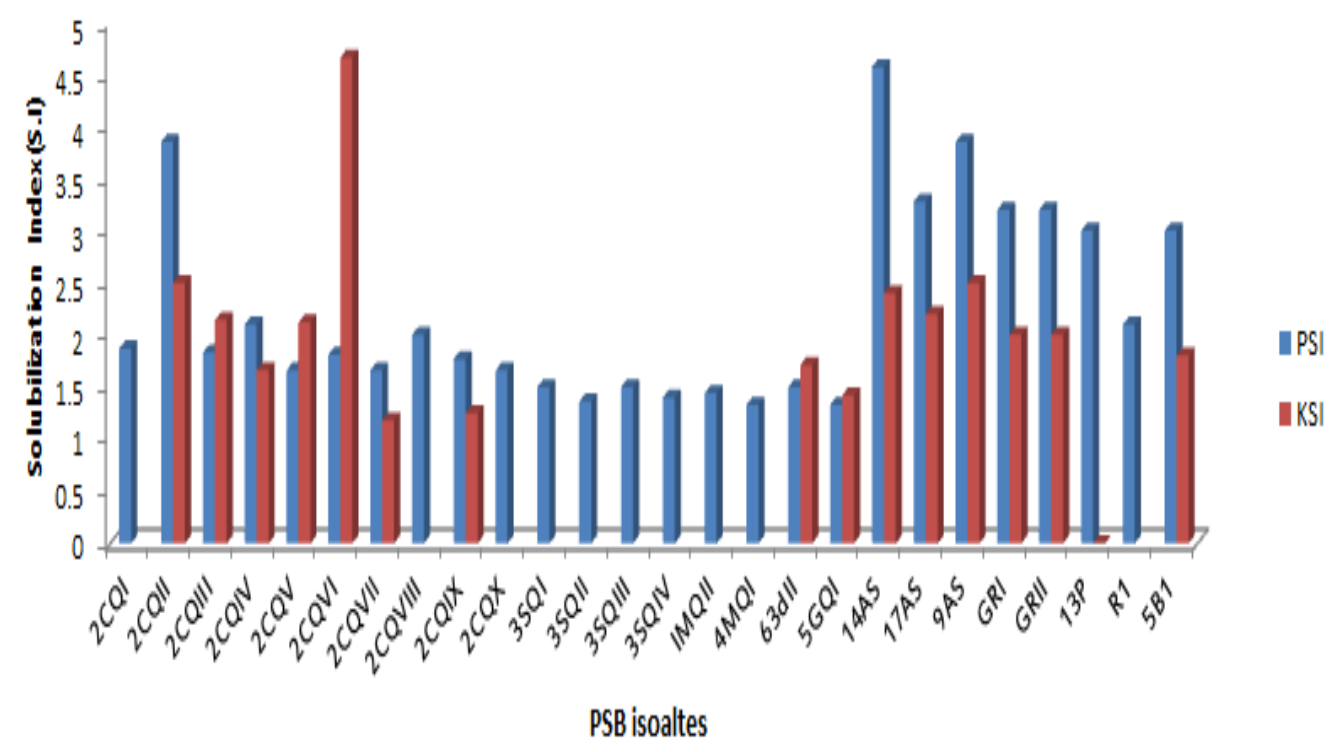

Figure 5. Comparison of solubilization index of selected PSB isolates on PVK and Aleksandrov media

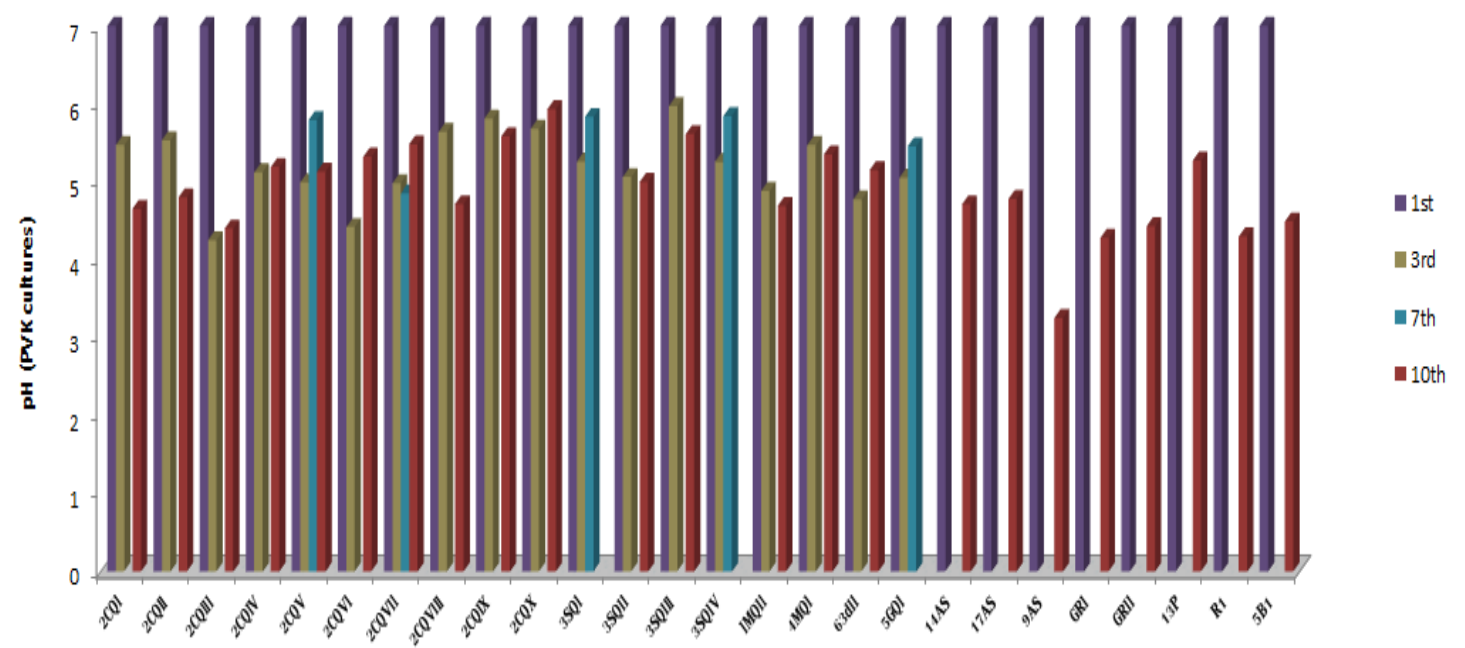

PSB isolates

Figure 6. $p H$ change in PVK broth medium inoculated with different PSB isolates

\section{Molecular characterization/identification of bacterial isolates}

For molecular characterization, genomic DNA of 9AS, 2CQ11, 2CQ11l, 14AS, 2CQIV, 2CQV, 17AS, 2CQV1, GR1, 5B1 and R1 PSB isolates was extracted and used as template for 16SrRNA amplification with universal primer set. DNA of 2CQ11l isolate was used as a template for optimizing the primer set's annealing temperature and run its gradient PCR. It displayed the single prominent band at $54{ }^{\circ} \mathrm{C}, 55^{\circ} \mathrm{C}$ and $56{ }^{\circ} \mathrm{C}$ 


$$
-10853 \text { - }
$$

of approximately $1.2 \mathrm{~kb}$ size (Fig. 7). Following the optimized recycling conditions ribotyping PCR was carried with genomic DNA of 6 potent isolates 2CQ11, 14AS, 2CQ1ll, 17AS, Rl and 5Bl as templates. In all strains PCR products of $1.2 \mathrm{~kb}$ was observed (Fig. 8). After ribotyping, the data for sequence analyses of PCR products were obtained from the DNA core facility of the CAMB and used it for molecular identification through in silico analysis. Thus by equating the 16SrRNA sequence database with all available data of gene bank through BLAST homology, inferred the isolates identification. On the base of close relations, experimental PSB isolates 2CQ1l, 14AS, 2CQ1ll, 17AS, R1 and 5B1 were identified as Enterobacter sp., Marine Bacterium, Klebsiella sp., Bacillus licheniformis, Staphylococcus warneri and Serratia marcescens, with the sequence similarity of 95\%, 93\%, 93\%, 94\%, 96\% and $96 \%$ respectively. Accession no was obtained by submitting their sequence data to NCBI. The identified PSB isolates are mentioned in Table 1. Phylogenetic trees were constructed by MEGA 6 software, shown in the Figure 9. Similarly, different PSB from the plant rhizosphere have been purified, characterized and reported by other researcher (Tariq et al., 2014; Dar et al., 2014; Rodríguez et al., 2000).

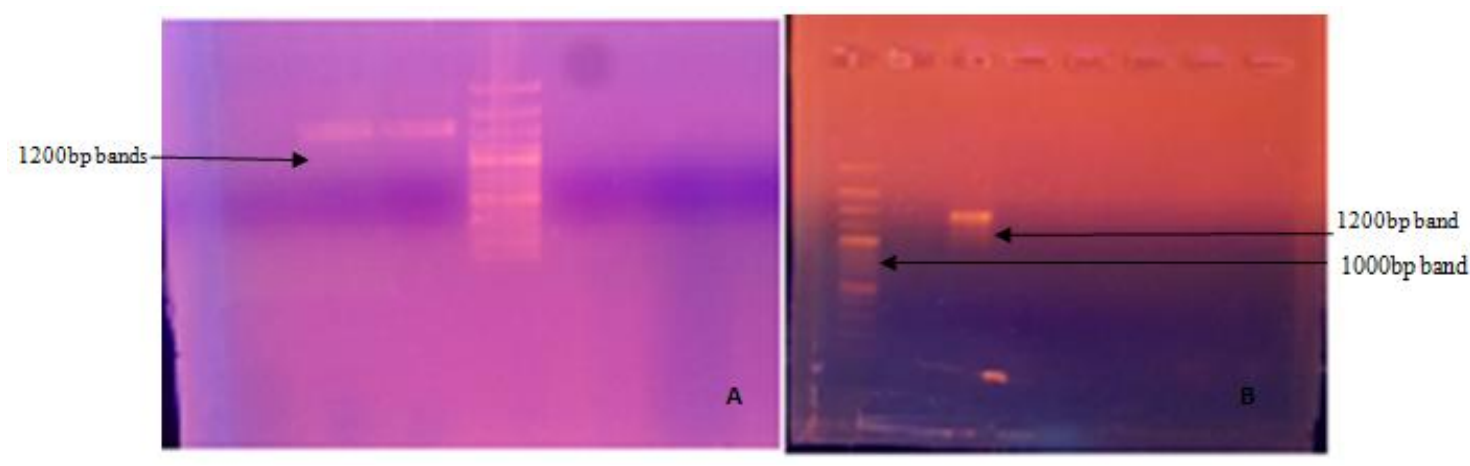

Figure7. Gradient PCR displaying ribotyping PCR result (1\% Agarose gel) of about $1200 \mathrm{bp}$ band (A) at $54{ }^{\circ} \mathrm{C}$ and $55^{\circ} \mathrm{C}(\mathrm{B})$ at $55^{\circ} \mathrm{C}$ with DNA of $14 A S$ (100 bp DNA ladder)

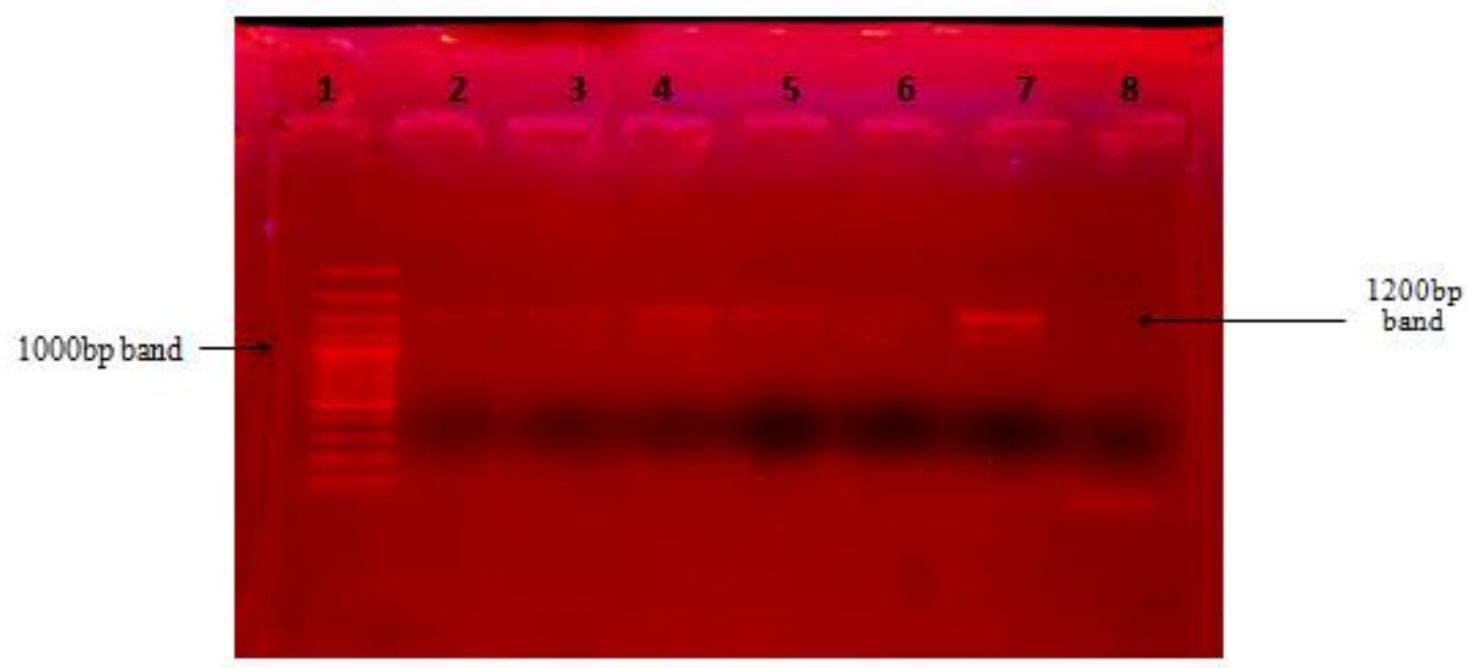

Figure 8. Ribotyping PCR showing the results at $55^{\circ} \mathrm{C}$ annealing $T$ with $1.2 \mathrm{~kb}$ band of selected PSB isolates (from 2-8) in respective order of 2CQll, 17AS, 2CQlll, 14AS, 5Bl, RI and control on $1 \%$ agarose gel with100 bp DNA ladder in first well 


$$
\text { - } 10854 \text { - }
$$

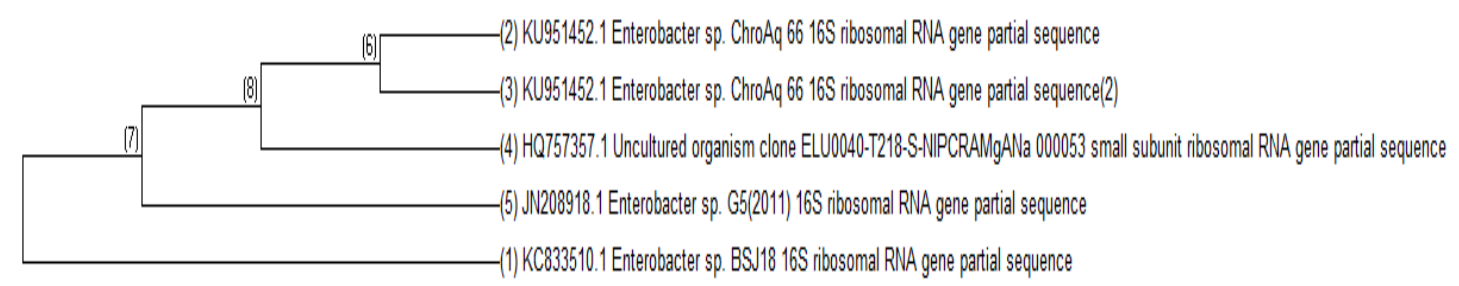

a

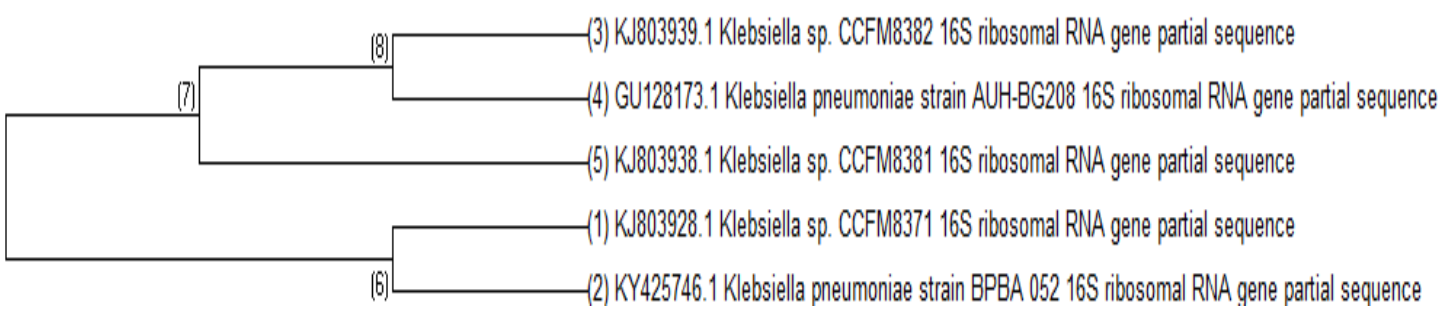

b
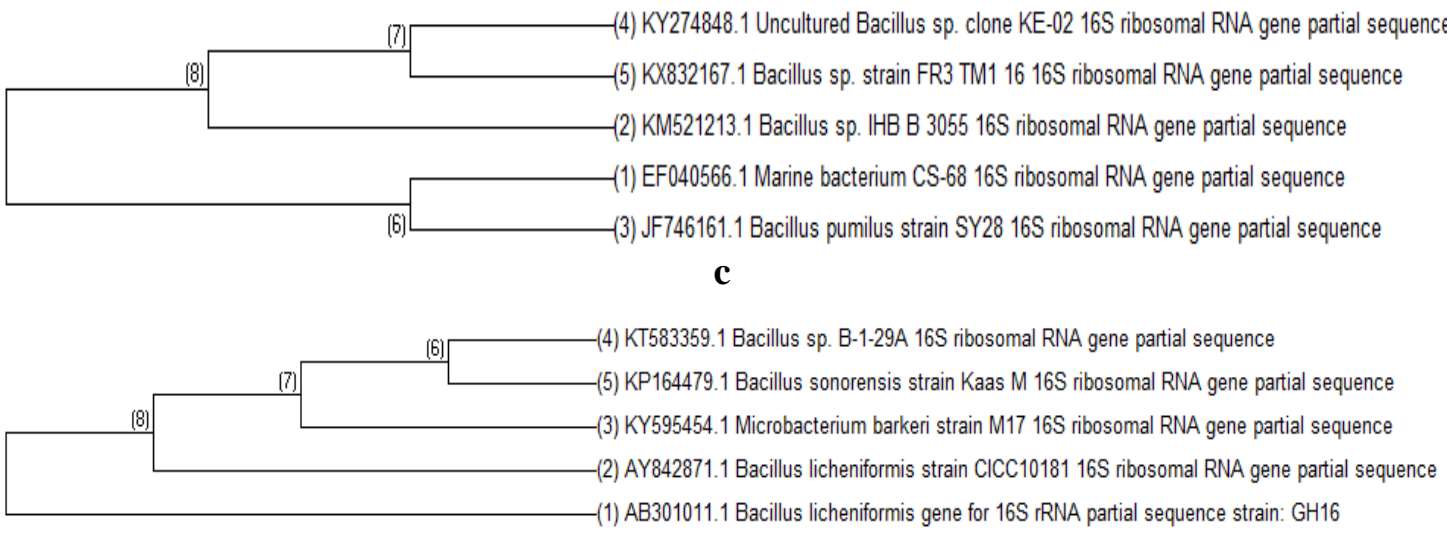

d

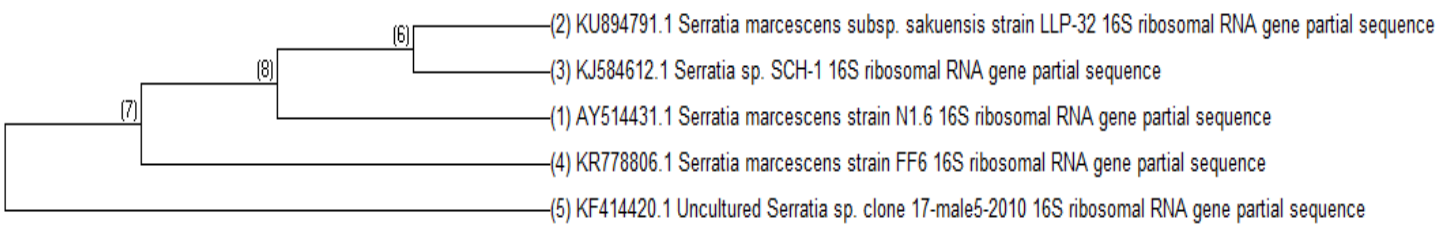

$\mathbf{e}$

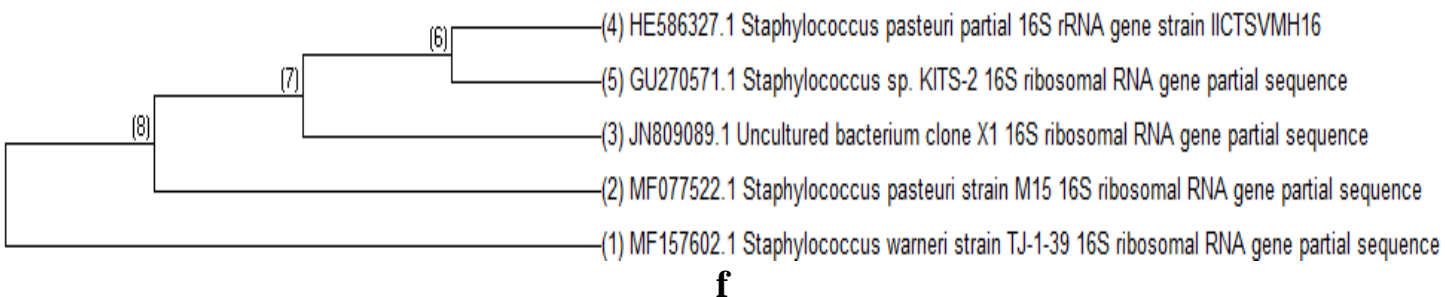

Figure 9. a Phylogenetic tree of 2CQll. b Phylogenetic tree of 2CQlll. $\boldsymbol{c}$ Phylogenetic tree of 14AS. $\boldsymbol{d}$ Phylogenetic tree of 17AS. $\boldsymbol{e}$ Phylogenetic tree of 5B1.f Phylogenetic tree of RI

\section{Field efficiency of CAMB biofertilizing agents in natural environment (on potato trial field)}

To evaluate their efficiency as phosphate biofertilizers in natural environment, three bacterial strains, the Bacillus licheniformis (14AS), Serratia marcescens (5B1), and 
Staphylococcus warneri (R1), were studied under natural environmental conditions. All three strains were found effective biofertilizers as more than double yield of potato tubers was obtained (Figs. 10F). Similar results were also reported by Malboobi et al. (2009) who evaluated efficiency of PSB on potato field trail and found significant yield in the growth of potato crops. Plants and tubers from control lanes and lanes treated with these three strains were compared. Very healthy and vigorous potato plants were observed in the experimental lanes that were treated with CAMB biofertilizer and showed significant results (Table 2). Harvesting of trial field with accumulated yield from all treatments and negative control are also shown in picture (Fig. 10). Significant differences $(\mathrm{P}<0.005)$ were observed between the values obtained for plant growth, number of lateral shoots, number of roots and root length of potato plants as compared to un- inoculated control plants (Table 2). These findings are in close accordance of Sadiq et al. (2013) who have performed pot experiments of similar nature. They have applied PSB isolates in the rhizosphere of sugarcane plant and found positive impact of PSB isolates on the plant growth. Mayak et al. (2014) have performed experiments on stress tolerance effect of rhizobacteria on tomato. They isolated plant growth promoting rhizobacteria from soil and applied selected strain (Achromobacter piechaudii) in tomato rhizosphere in salty soil conditions. During their study they found that application of bacteria caused enhanced growth of tomato plants. Further they have linked enhanced salt stress tolerance of tomato plants with enhanced uptake of potassium and phosphorous. Findings of Mayak et al. (2014) and Hosni et al. (2016) support the outcome of presented study. Furthermore, our study explains that rhizospheric application of plant growth promoting bacteria (phosphate and potassium solubilizing bacteria) enhance absorbable phosphate and potassium in the root area of plants. Similar results have also been reported by many others who have concluded up with enhanced overall plant production in the influence of PSB application in rhizosphere of pot and trial field plants (Khalid et al., 2004; Çakmakçi et al., 2006; Wu et al., 2005). The results reported by Wu et al. (2005) have reported the highest biomass and seedling height in the plants of Zea mays trial field treated with PSB. Although several studies have been reported on the plant growth promoting effect of PSB in trial field, this is the first report on the rhizospheric application of PSB in the trial field of transgenic potato variety. The plants of treated lanes possessed dehydrin-10 gene of Eucalyptus globulus for tolerance against multiple abiotic stresses and produced about three folds enhanced potato yield and biomass over untreated lanes. The survival of tissue cultured plants in trial field lanes treated with PSB was also amazing and the higher survival rate may also be linked with antifungal activity of PSB strains as described by Jahangir et al. (2016).

Table 1. Identified PSB isolates (based on sequencing and in silico studies) with assigned accession numbers

\begin{tabular}{c|c|c|c|c|l}
\hline $\begin{array}{c}\text { Serial } \\
\text { no. }\end{array}$ & Isolate code & Gene bank no. & Closely related in database & $\begin{array}{c}\text { Maximum } \\
\text { identity (\%) }\end{array}$ & Accession no. \\
\hline 1 & $2 \mathrm{CQ} 1 \mathrm{l}$ & $\mathrm{KC} 833510.1$ & Enterobacter sp. & 95 & MF465779 \\
2 & $14 \mathrm{AS}$ & $\mathrm{AB} 301011.1$ & Bacillus licheniformis & 94 & MF465782 \\
3 & $17 \mathrm{AS}$ & $\mathrm{EF} 040566.1$ & Marine Bacterium & 93 & MF465781 \\
4 & $2 \mathrm{CQIII}$ & $\mathrm{KJ} 803928.1$ & Klebsiella sp. & 93 & MF465778 \\
5 & $5 \mathrm{~B} 1$ & $\mathrm{AY} 514431.1$ & Serratia marcescens & 96 & MF465783 \\
6 & $\mathrm{R} 1$ & MF157602.1 & Staphylococcus warneri & 96 & MF465777 \\
\hline
\end{tabular}



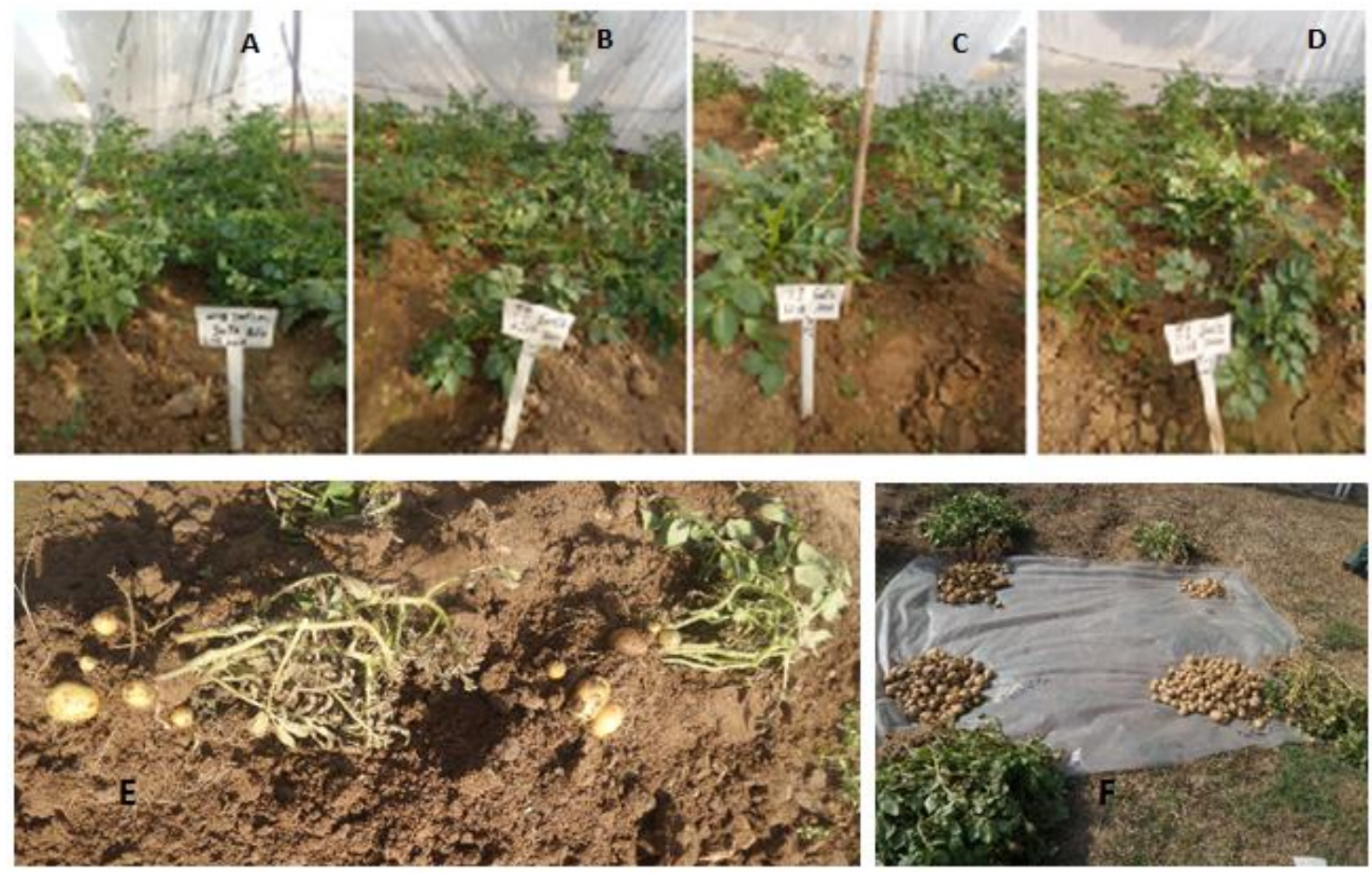

Figure 10. Different treatments upon potato plants in trial field and its harvesting. A Control line; $\boldsymbol{B}-\boldsymbol{D}$ Experimental lines treated with Bacillus licheniformis, Serratia marcescens, and Staphylococcus warneri respectively. $\boldsymbol{E}-\boldsymbol{F}$ Harvesting of trial field with accumulated yield from all treatments and negative control

Table 2. Effect of PSB on growth parameters in potato trial field

\begin{tabular}{c|c|c|c|c|c}
\hline \multicolumn{6}{c}{ Plant growth parameters (90 days) } \\
\hline Sr. no & Bacterial isolates & Plant height & No. of lateral shoots & No. of roots & Max root length \\
\hline 1 & 5B1 & $21.7 \pm 1.337^{\mathrm{a}}$ & $13.7 \pm 0.969^{\mathrm{a}}$ & $35.3 \pm 4.23^{\mathrm{a}}$ & $6.7 \pm 0.471^{\mathrm{a}}$ \\
2 & R1 & $22.0 \pm 0.785^{\mathrm{a}}$ & $13.7 \pm 1.416^{\mathrm{a}}$ & $27.4 \pm 2.008^{\mathrm{ab}}$ & $10.7 \pm 3.504^{\mathrm{a}}$ \\
3 & $14 \mathrm{AS}$ & $20.9 \pm 1.036^{\mathrm{ab}}$ & $11.5 \pm 1.815^{\mathrm{a}}$ & $19.9 \pm 1.086^{\mathrm{b}}$ & $7.6 \pm 0.304^{\mathrm{a}}$ \\
4 & Control & $18.6 \pm 0.967^{\mathrm{b}}$ & $12.4 \pm 1.286^{\mathrm{a}}$ & $32.6 \pm 3.766^{\mathrm{a}}$ & $7.0 \pm 0.365^{\mathrm{a}}$ \\
\hline
\end{tabular}

Each value is an average of replicates; \pm denotes standard error mean among these replicates and numbers followed by different letters differs significantly at $\mathrm{P}<0.005$

\section{Conclusion}

The effects of this study demonstrated that Phosphate Solubilizing Bacteria play a vital role in plant nutrition, convert the insoluble phosphorus into the available form to the florae and used as biofertilizers for agricultural crops. Phosphate solubilizing bacteria identified by molecular characterization performed efficiently in natural environment and more than double potato yield was obtained as compared to untreated control plants in potato trial field. On the basis of this investigation, further studies are necessary to investigate possible synergistic effects of rhizospheric bacteria since the use of these bio-fertilizers can be used in an ideal harvesting system with a control effects on the environment sustainable manner in agricultural soils. Furthermore, use of these beneficial microbes not only reduces need of phosphate fertilizer for crop plant 
rather it plays some important role in plant growth parameter. Therefore, more research is needed to investigate the Phosphate Solubilizing Bacteria (PSB) as bio-inoculants to enhance the sustainable management of soil and agriculture that could help in economic stability and environment friendliness.

Acknowledgements. Very passionate thanks are paid to Mr. Islam Khan (CEMB) for his generous help. We are also very thankful to the CAMB DNA Core Facility (especially Mr. Muhammad Usman and Mr. Muhammad Akram) and Proteomics Lab CAMB for their kind cooperation during execution of this work.

\section{REFERENCES}

[1] Ali, Q., Ahsan, M., Ali, F., Aslam, M., Khan, N. H., Munzoor, M., Mustafa, H. S. B., Muhammad, S. (2013): Heritability, heterosis and heterobeltiosis studies for morphological traits of maize (Zea mays L.) seedlings. - Advancements in Life Sciences 1(1) 52-63.

[2] Ali, Q., Ali, A., Ahsan, M., Ali, S., Khan, N. H., Muhammad, S., Abbas, H. G., Nasir, I. A., Husnain, T. (2014): Line $\times$ Tester analysis for morpho-physiological traits of Zea mays L. seedlings. - Advancements in Life Sciences 1(4): 242-253.

[3] Ali, Q., Ahsan, M., Malook, S., Kanwal, N., Ali, F., Ali, A., Ahmed, W., Ishfaq, M., Saleem, M. (2016): Screening for drought tolerance: comparison of maize hybrids under water deficit condition. - Advancements in Life Sciences 3(2): 51-58.

[4] Awais, M., Tariq, M., Ali, A., Ali, Q., Khan, A., Tabassum, B., Nasir, I. A., Husnain, T. (2017): Isolation, characterization and inter-relationship of phosphate solubilizing bacteria from the rhizosphere of sugarcane and rice. - Biocatalysis and Agricultural Biotechnology 11: 312-321.

[5] Çakmakçi, R., Dönmez, F., Aydın, A., Şahin, F. (2006): Growth promotion of plants by plant growth-promoting rhizobacteria under greenhouse and two different field soil conditions. - Soil Biology \& Biochemistry 38: 1482-1487.

[6] Dale, P. J., McPartlan, H. C. (1992): Field performance of transgenic potato plants compared with controls regenerated from tuber discs and shoot cuttings. - Theoretical and Applied Genetics 84(5-6): 585-591.

[7] Dar, A. I., Saleem, F., Ahmad, M., Tariq, M., Khan, A., Ali, A., Tabassum, B., Ali, Q., Khan, G. A., Rashid, B., Nasir, I. A. (2014): Characterization and efficiency assessment of PGPR for enhancement of rice (Oryza sativa L.) yield. - Advancements in Life Sciences 2(1): pp.38-45.

[8] Diep, C. N., Hieu, T. N. (2013): Phosphate and potassium solubilizing bacteria from weathered materials of denatured rock mountain, Ha Tien, Kien Giang Province, Vietnam. - American Journal of Science 1(3): 88-92.

[9] Glick, B. R. (2001): Phytoremediation, synergistic use of plant and bacteria to clean up the environment. - Biotechnology Advances 21(3): 83-393.

[10] Hosni, F., Asgharzadih, A., Ardakani, M., Hamidi, A. (2016): The impact of potato minituber inoculation with plant growth promoting rhizobacteria on tuber yield and nutrients uptake. - Crops Improvement 17: 911-924.

[11] Jahangir, G. Z., Sadiq, M., Hassan, N., Nasir, I. A., Saleem, M. Z., Iqbal, M. (2016): The effectiveness of phosphate solubalizing bacteria as biocontrol agents. - Journal of Animal and Plant Science 26(5): 1313-1319.

[12] Khalid, A., Arshad, M. Zahir, Z. A. (2004): Screening plant growth promoting rhizobacteria for improving growth and yield of wheat. - Journal of Applied Microbiology 96: 473-480. 
[13] Laticia, A., Fernandez, Agaras, B., Wall, L. G., Valverde, C. (2015): Abundance and ribotypes of phosphate-solubilizing bacteria in Argentinean agricultural soils under no-till management. - Annual Reviews of Microbiology 65(3): 1667-1678.

[14] Malboobi, M. A., Behbahani, M., Madani, H., Owlia, P., Deljou, A., Yakhchali, B., Moradi, M., Hassanabadi, H. (2009): Performance evaluation of potent phosphate solubilizing bacteria in potato rhizosphere. - World Journal of Microbiology and Biotechnology 25: 1479-1484. DOI: 10.1007/s11274-009-0038-y.

[15] Mayak, S., Tirosh, T., Glick, B. R. (2004): Plant growth-promoting bacteria confer resistance in tomato plants to salt stress. - Plant Physiology and Biochemistry 42(6): 565572.

[16] Nobandegani, M. B. J., Saud, H. M., Yun, W. M. (2015): Phylogenetic relationship of phosphate solubilizing bacteria according to 16S rRNA genes. - BioMed Res. Intl. 2015: $1-5$.

[17] Pérez, E., Sulbarán, M., Ball, M. M., Yarzábal, L. A. (2007): Isolation and characterization of mineral phosphate-solubilizing bacteria naturally colonizing a limonitic crust in the south-eastern Venezuelan region. - Soil Biology and Biochemistry 39: 2905-2914.

[18] Rodríguez, H., Gonzalez, T., Selman, G. 2000. Expression of a mineral phosphate solubilizing gene from Erwinia herbicola in two rhizobacterial strains. - J. Biotechnol. 84(2): 155-161.

[19] Sadiq, H. M., Jahangir, G. Z., Nasir, I. A., Iqtidar, M., Iqbal, M. (2013): Isolation and characterization of phosphate-solubilizing bacteria from rhizosphere soil. Biotechnology Biotechnological Equipments 27(6): 4248-4255.

[20] Sharma, S., Kumar, V., Tripathi, R. B. (2011): Isolation of phosphate solubilizing microorganism (PSMs) from soil. - Journal of Microbiology and Biotechnology Research 1(2): 90-95.

[21] Shekhar, N. C., Bhaclauriay, S., Kumar, P., Lal, H., Mondal, R., Verma, D. (2000): Stress induced phosphate solubilization in bacteria isolated from alkaline soils. - FEMS Microbiology Letters 182(2): 291-296.

[22] Sheng, X. F., Xia, J. J., Chen, J. (2003): Mutagenesis of the Bacillus edaphicus strain NBT and its effect on growth of chilli and cotton. - Agricultural Sciences of China 2: 400-412.

[23] Sindhu, S. S., Dua, S., Verma, M. K., Khandelwal, A. (2010): Growth Promotion of Legumes by Inoculation of Rhizosphere Bacteria. - In: Khan, M. S. et al. (eds.) Microbes for Legume Improvement. - Springer, Vienna, pp. 195-235.

[24] Skogsmyr, I. (1994): Gene dispersal from transgenic potatoes to conspecifics: a field trial. - Theoretical and Applied Genetics 88(6-7): 770-774.

[25] Surapat, W., Pukahuta, C., Rattanachaikunsopon, P., Tadanori, A., Sophon, B. (2013): Characteristics of phosphate solubilization by phosphate-solubilizing bacteria isolated from agricultural chilli soil and their efficiency on the growth of chilli (Capsicum frutescens L. cv. Hua Rua). - Chiang Mai Journal of Science 40(1): 11-25.

[26] Tariq, M., Ali, Q., Khan, A., Khan, G. A., Rashid, B., Rahi, M. S., Ali, A., Nasir, I. A., Husnain, T. (2014): Yield potential study of Capsicum annuum L. under the application of PGPR. - Advancements in Life Sciences 1(4): 202-207.

[27] Wu, S. C., Cao, Z. H., Li, Z. G., Cheung, K. C., Wong, M. H. (2005): Effects of biofertilizer containing $\mathrm{N}$-fixer, $\mathrm{P}$ and $\mathrm{K}$ solubilizers and $\mathrm{AM}$ fungi on maize growth: a greenhouse trial. - Geoderma 125(1-2): 155-166.

[28] Yasmin, H., Bano, A. (2011): Isolation and characterization of phosphate solubilizing bacteria from rhizosphere soil of weeds of khewra salt range and attock. - Pakistan Journal of Botany 43(3): 1663-1668.

[29] Zameer, M., Tabassum, B., Ali, Q., Tariq, M., Zahid, H., Nasir, I. A., Akram, W., Baqir, M. (2015): Role of PGPR to improve potential growth of tomato under saline condition: An overview. - Life Science Journal 12(3s): pp.54-62. 


$$
-10859 \text { - }
$$

[30] Zameer, M., Zahid, H., Tabassum, B., Ali, Q., Nasir, I. A., Saleem, M., Butt, S. J. (2016): PGPR potentially improve growth of tomato plants in salt-stressed environment. Turkish Journal of Agriculture - Food Science and Technology 4(6): pp.455-463.

[31] Zhang, C., Kong, F. (2014): Isolation and identification of potassium-solubilizing bacteria from tobacco rhizospheric soil and their effect on tobacco plants. - Applied Soil Ecology 82: 18-25. 